\title{
Uma breve, mas elementar reflexão
}

\section{CITAÇÃO \\ Duarte, L. V.(2020) \\ Uma breve, mas elementar reflexão, Rev. Ciência Elem., V8(01):001. doi.org/10.24927/rce2020.001}

\section{EDITOR}

José Ferreira Gomes, Universidade do Porto

\section{PUBLICADO EM}

28 de fevereiro de 2020

\section{COPYRIGHT}

(C) Casa das Ciências 2020.

Este artigo é de acesso livre, distribuído sob licença Creative Commons com a designação CC-BY-NC-SA 4.0, que permite a utilização e a partilha para fins não comerciais, desde que citado 0 autor e a fonte original do artigo.

\section{rce.casadasciencias.org}

Iniciamos um novo ano, o oitavo da vida da Revista de Ciência Elementar (RCE), sendo tempo dos naturais desejos das melhores venturas e elevados ensejos profissionais. $E$ em tempos cada vez mais exigentes (...). Assumindo o calendário gregoriano, o presente ano de 2020 marca o final de uma década. Decénio em que se assistiu e se consolidou uma autêntica revolução no modo como temos acesso ao conhecimento científico, como tratamos essa informação e como a comunicamos. Sendo a nossa comunidade composta de agentes na arte de ensinar, com sérias responsabilidades na transmissão do conhecimento, urge alguma reflexão sobre este tema. Aproveito este espaço para esse efeito.

Estamos no final de uma década durante a qual tudo mudou não só quanto à forma como lidamos com a difusão da informação científica, como ao modo como a ela temos acesso. Hoje, não necessitamos de sair de casa, largar a comodidade de um qualquer teclado para termos acesso à novidade científica, muitas vezes a uma velocidade que suplanta o timing da própria publicação! 0 que é realmente espantoso e que não tem preço - a não ser o possível valor que algumas revistas obrigam a despender pelo acesso a esse conhecimento (!). As revistas científicas que deixaram o formato em papel, quase desconhecido das novas gerações, adotaram integralmente o digital, porque assim manda a pressa da disseminação da informação, a favor da tão propalada "sustentabilidade". 0 resultado é o empobrecimento das bibliotecas tradicionais. São os novos tempos em que uma produção científica se confunde com o seu bilhete de identidade, o DOI (digital object identifier), ao qual, curiosamente, a RCE já aderiu. Tudo muito rápido e acessível na hora de uma eventual busca bibliográfica, a contrastar com o mesmo ritual de há três décadas, em que se esperava a hora de determinada revista chegar aos escaparates das bibliotecas, sendo o seu índice uma autêntica surpresa! Vivemos então num período promissor, tanto para o investigador, que vive permanentemente ávido de novidades e de perceber o impacto da sua investigação, como para qualquer agente de ensino, na sustentação da sua prática letiva diária e na atualização contínua dos seus conhecimentos.

A ciência está assim disponível a todos. E não é de ninguém. Nem exclusiva do autor ou autores dos estudos científicos, nem se encerra nos conceitos e premissas, que resultaram de investigações mais ou menos robustas. Embora os obreiros sejam, em determinados contextos, cada vez mais esquecidos na hora em que as ideias passam para o papel dos novos tempos, a internet. Nada estará perdido se as clássicas referências bibliográficas forem convertidas na linguagem moderna, através de um DOI ou de um link! Mesmo assim, uma ciência sem rosto. Mas todo este novo paradigma parece ter um lado que nos deverá reservar alguma inquietação. Eu diria mais, muita preocupação. Algo cada vez mais visível na praxis dos relatórios académicos, desenvolvidos pelos nos- 
sos estudantes universitários, onde já se chegou ao extremo em que pode valer tanto uma página de uma revista científica consagrada, como uma notícia jornalística - a má, será obviamente, ainda pior -, um excerto de um blog ou uma imagem plasmada nas redes sociais virtuais, comentada com aparente boa vontade, mas de forma nada refletida. A simplicidade do ato de googlar contraria a aparente habilidade para encontrar o sítio certo para aceder à informação científica mais fidedigna. 0 sério problema da validação da informação. Como consequência, o culto de uma informação científica com base em fontes que não o são, da inexistência de escrutínio, a que acresce a ausência de espírito crítico por parte do usuário. A atitude que se tornou comum é a facilidade com que se copia informação científica - é desta que falamos -, tantas vezes de forma incorreta, e como é promovida no quotidiano, seja qual for o canal. Sem o mínimo de critério e a falta de discernimento de que se está a contribuir para alguma entropia. Até vou mais longe, é o caos. Estamos na era onde se confunde conhecimento científico, comunicação científica, com tudo o resto, pouco ou nada sustentado. 0 pior, o culto e a perpetuação do erro. No pico do alarme, estão as novas gerações que têm os olhos no mundo global. Ou seja, em tudo o que é "acumulado" na internet. Onde aquilo que é correto e incorreto, em matéria científica, parece não fazer grande diferença. É neste estado de graça, que todos temos que tentar corrigir este caminho. Fica o pedido de reflexão...e de ação. Mesmo sabendo que a perfeição nunca será atingida.

\section{Luís Vítor Duarte}

Editor Convidado 